\title{
Atomic force microscopy studies of formation of black silicon by reactive ion etching
}

\begin{abstract}
Black silicon (BSi), a surface modification of silicon, can be fabricated by various methods such as Electrochemical Etching, Metal Assisted Chemical Etching, Laser Method, etc. The fabrication of BSi by Reactive Ion Etching (RIE), under various pressures and for different etch durations, is presented in this study. The influence of pressure and etch time on the surface roughness of the resulting BSi is investigated and compared with the literature.
\end{abstract}

Volume 2 Issue 4 - 2018

\section{Asahel Bañobre, Sita Rajyalaxmi Marthi, Ravindra NM}

New Jersey Institute of Technology, Newark, New Jersey 07102, USA

\begin{abstract}
Correspondence: Ravindra NM, New Jersey Institute of Technology, Newark, New Jersey 07I02, USA, Email nmravindra@gmail.com
\end{abstract}

Received: June 13,2018 | Published: August 27, 2018

\section{Introduction}

Black Silicon (BSi), a surface modification of silicon, is being used in a variety of applications including image sensors, bio-sensors, Micro-Electro Mechanical Structures (MEMS), light-emitting devices, anti-reflection coatings and antibacterial coatings. ${ }^{1-4}$ The unusually low reflectance and high absorptance of BSi make it an attractive candidate in silicon solar cell technology. ${ }^{5-8}$ Several methods have been used to process BSi. These methods include the following: Metal Assisted Chemical Etching, ${ }^{9-16}$ Electrochemical Etching ${ }^{17-19}$ and Laser Method. ${ }^{19-27}$ Non-conventional etching techniques may be hazardous, complex and not easily scalable. ${ }^{28}$

In the present study, we utilize the conventional Reactive Ion Etching (RIE) method for the processing of BSi. The formation of BSi structures with varying etch conditions is presented. An Oxford PlasmaPro NGP0 RIE system is utilized in these experiments. The Oxford PlasmaPro NPG80 RIE is an open-load medium plasma density system configured for fluorine-based etch chemistries, which can accommodate pieces to wafers up to 8 " in diameter and $3 \mathrm{~cm}$ thick. The rate of flow of gases, $\mathrm{SF}_{6}, \mathrm{O}_{2}$ and $\mathrm{CHF}_{3}$, is fixed. The chamber pressure and etch time have been varied to study the surface structure formation.

\section{Reactive ion etching}

The use of RIE for the formation of grass like BSi structures was first reported by Jansen et al. around 1995. 29,30 The RIE system consists of two parallel-plate electrodes. One wafer may be loaded onto the bottom electrode, called the cold cathode, for each run. A high vacuum is formed using a turbomolecular pump. The gases are supplied from the edge of the upper electrode..$^{31}$ The RIE process can provide high rates of isotropic etching, which makes it possible to vary the etch directionality between isotropic and anisotropic etching using $\mathrm{SF}_{6} / \mathrm{O}_{2}$ at various flow rates. ${ }^{32} \mathrm{In} \mathrm{SF}_{6} / \mathrm{O}_{2} / \mathrm{CHF}_{3}$ plasma, each gas has its specific function and influence. The etch profile may be controlled by varying the flow rates of the gases.

$\mathrm{SF}_{6}$ produces $\mathrm{F}^{*}$ radicals for the chemical etching of silicon by forming volatile $\mathrm{SiF}_{4}$. $\mathrm{O}_{2}$ creates $\mathrm{O}^{*}$ radicals to passivate the surface of $\mathrm{Si}$ wafer with $\mathrm{SiO}_{x} \mathrm{~F}_{\mathrm{y}} . \mathrm{SF}_{\mathrm{x}}$ radicals remove the oxyflouride. The $\mathrm{CHF}_{3}$ gas is almost an independent source of oxyflouride etch ions.
These gases are responsible for the highly controllable profiles at very low ion energies and also high etch rates. The low ion energy prevents substrate damage, and makes it easy to change the profile of the trench. The ion energy is governed by the potential which is developed between the plasma and the powered electrode, the DC self-bias. Gases such as $\mathrm{O}_{2}$ and $\mathrm{CHF}_{3}$ are used at high bias voltages, whereas $\mathrm{SF}_{6}$ requires very low voltage. The $\mathrm{SF}_{6} / \mathrm{O}_{2} / \mathrm{CHF}_{3}$ etching mechanism is shown in Figure 1.

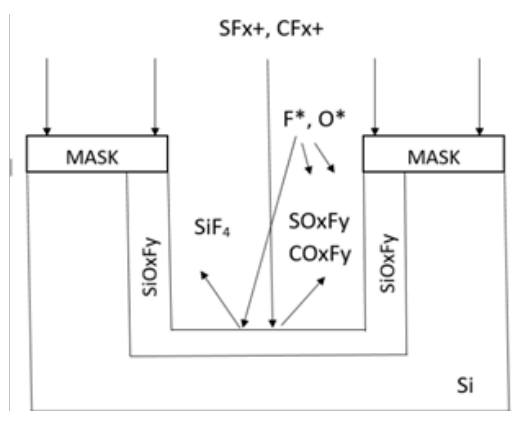

Figure IThe $\mathrm{SF}_{6} / \mathrm{O}_{2} / \mathrm{CHF}_{3}$ chemistry \{based on Figure from\}. ${ }^{29}$

\section{Experimental details}

In the present study, single side polished $\mathrm{p}$-type $<100>\mathrm{CZ}$ wafers with substrate resistivity of $0.010-0.020 \Omega-\mathrm{cm}, 5$-inch diameter and $600 \mu \mathrm{m}$ thickness are used. The wafers are cut to 1 square inch samples after standard cleaning. $\mathrm{SF}_{6}, \mathrm{O}_{2}$ and $\mathrm{CHF}_{3}$ gases are used for the etching process with flow rates of $33 \mathrm{sccm}, 11 \mathrm{sccm}$ and $13 \mathrm{sccm}$ respectively. Chamber pressures are varied from 60 mTorr to 100 mTorr. The plasma power is maintained at $100 \mathrm{~W}$ for all the etching processes. Various conditions of etching, implemented in this study, are summarized in Table 1. Fifteen to twenty samples were prepared for each process run. Out of these, five were used for AFM measurements. The AFM results, presented in this study, represent a characteristic image for each process. Average of the results of roughness has been presented in Table 2. A Bruker Atomic Force Microscope, Model Dimension FastScan, has been utilized in acquiring the AFM images. 
Table I Summary of etch conditions used in the present study.

\begin{tabular}{lll}
\hline Sample & $\begin{array}{l}\text { Pressure } \\
\text { (mTorr) }\end{array}$ & $\begin{array}{l}\text { Etch time } \\
\text { (minutes) }\end{array}$ \\
\hline Sample A & 100 & 10 \\
Sample B & 100 & 20 \\
Sample C & 100 & 30 \\
Sample D & 80 & 10 \\
Sample E & 60 & 10 \\
Sample F & 60 & 15 \\
\hline
\end{tabular}

\section{Results and discussion}

AFM images of six samples, processed in this study, are presented in Figure 2. This figure shows the distribution of varying surface
Table 2 Summary of roughness and structure profile.

\begin{tabular}{lll}
\hline Sample & $\begin{array}{l}\text { Roughness } \\
(\mathbf{n m})\end{array}$ & Structure profile \\
\hline Sample A & 20.4 & Columnar \\
Sample B & 29.1 & Pyramidal \\
Sample C & 11 & Non-uniform pyramids \\
Sample D & 69 & Columnar \\
Sample E & 45.9 & Pyramidal \\
Sample F & 51.1 & Pyramidal \\
\hline
\end{tabular}

roughness for the samples. It may be observed that, at higher pressures, the trenches are wider than that at lower pressures. The roughness varies between $11 \mathrm{~nm}$ to $69 \mathrm{~nm}$. The $3 \mathrm{D}$ view of the AFM image, showing the roughness, is presented in Figure 3.

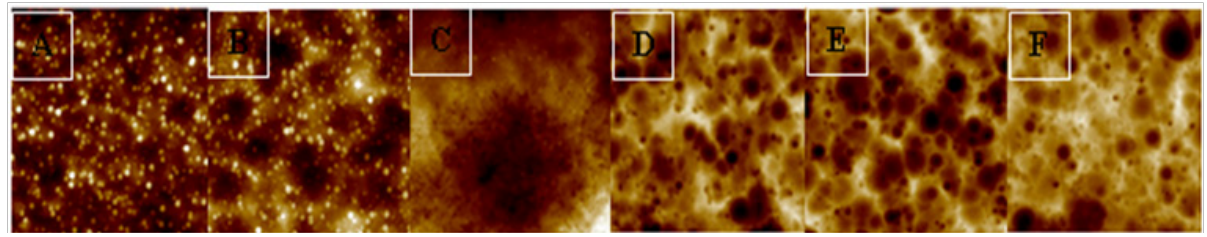

Figure 2 Top view of Samples A-F.The corresponding viewing areas of samples, imaged under the AFM, are $4 \mu \mathrm{m}^{2}$.
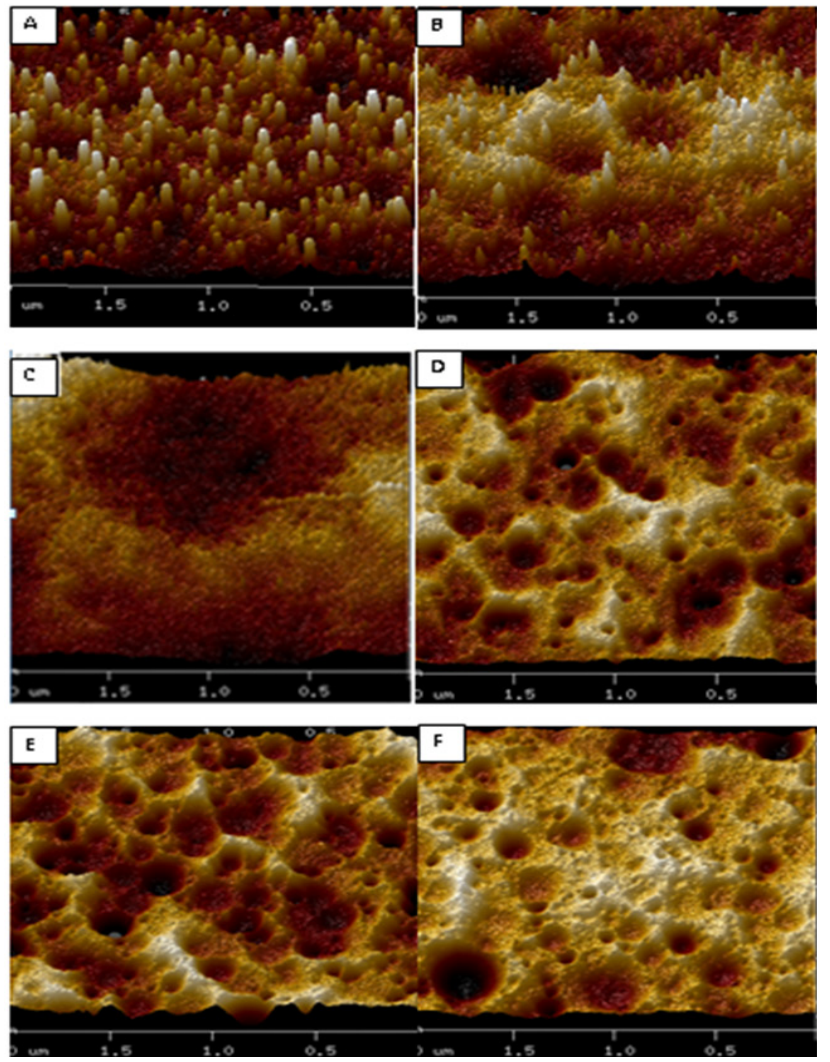

Figure $33 \mathrm{D}$ view of Samples A-F.The corresponding viewing areas of samples, imaged under the AFM, are $4 \mu \mathrm{m}^{2}$. 
At a pressure of 100 mTorr, for 10 minute etch duration (sample A), the resulting structures are columnar structures of roughness 20.4 $\mathrm{nm}$. For higher etch durations, viz., 20 minutes and 30 minutes, the structures are pyramidal and non-uniform pyramidal structures with roughness of $29.1 \mathrm{~nm}$ and $11 \mathrm{~nm}$ respectively. Further, at $80 \mathrm{mTorr}$, for 10 minute etch duration, the structures formed are columnar. The roughness of the sample is about $69 \mathrm{~nm}$. With further decrease in chamber pressure, at 60 mTorr, 10 minute etch results in pyramidal structures with roughness of $45.9 \mathrm{~nm}$. At the same pressure, for longer etch time of 15 minutes; the resulting structures are pyramidal with roughness of $\sim 51 \mathrm{~nm}$.

For higher pressures, i.e. $100 \mathrm{mTorr}$ in these experiments, the surface of the silicon sample consists of holes of increasing diameter throughout its surface area. Increase in pressure and etch time leads to increase in the recombination of $\mathrm{F}^{*}$ radicals. Since all the processes have similar gas flow rates, the uncombined $\mathrm{F}^{*}$ and $\mathrm{O}^{*}$ radicals have increased times to react with the silicon as the etch times increase. However, for etch times greater than 20 minutes, the holes formed are larger and the roughness of the surface is decreased as the higher pressure reduces the energy of the delivered ions.

The roughness is observed to be maximum for a pressure of 80 mTorr for etch time of ten minutes. The summary of roughness and structure of the resulting profile is summarized in Table 2 .

Figure 4 shows the AFM images of microstructures of black silicon wafers with different texturing conditions. Zhong et al., ${ }^{33}$ have utilized Plasma Immersion Ion Implantation method ${ }^{33}$ for processing black silicon. Figure 4 shows that the black silicon surfaces are covered with dense nano hillocks, and the roughnesses of the nano hillocks are $150 \mathrm{~nm}, 300 \mathrm{~nm}$ and $600 \mathrm{~nm}$ for the surfaces of the C1 textured, C3 textured and $\mathrm{C} 5$ textured, respectively.

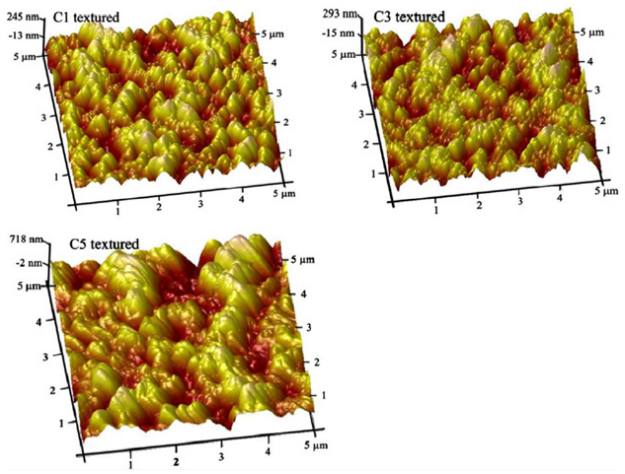

Figure 4 AFM images of microstructures of black silicon wafers with different texturing conditions. ${ }^{33}$

Figure 5 shows AFM surface scans obtained by Dekkers et al., ${ }^{34}$ for different RIE etching conditions. The profile of the resulting BSi structure in both the studies is pyramidal. The structure and roughness of BSi obtained by various research groups, in the literature, is tabulated and is compared with the present study in Table 3. The difference in the size of roughness of BSi structures is due to the difference in the rate of flow of gases and difference in applied chamber pressure.

Table 3 Comparison of structure profile and roughness of BSi.

\begin{tabular}{llll}
\hline Study & Roughness & Process & $\begin{array}{l}\text { Structure } \\
\text { profile }\end{array}$ \\
\hline Present Study & $69.0 \mathrm{~nm}^{*}$ & RIE & Columnar \\
\hline
\end{tabular}

\begin{tabular}{llll} 
Table Continued & & & \\
\hline Study & Roughness & Process & $\begin{array}{l}\text { Structure } \\
\text { profile }\end{array}$ \\
\hline Zhong et al. $^{33}$ & $600 \mathrm{~nm}$ & PIII & Nano hillocks \\
Mazur et al. $^{21}$ & $40 \mu \mathrm{m}$ & Laser & Spikes \\
Su et al. ${ }^{4}$ & $470 \mathrm{~nm}$ & $\begin{array}{l}\text { Wet } \\
\text { Etching }\end{array}$ & Micro-columns \\
\hline
\end{tabular}

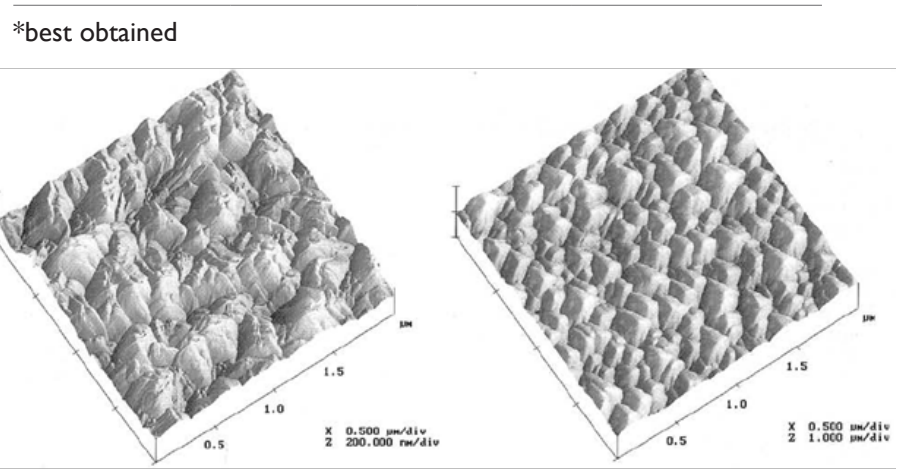

Figure 5 AFM surface scans, obtained by different RIE conditions. ${ }^{34}$

\section{Conclusions}

Reactive Ion Etching (RIE) has been utilized to form BSi with varying morphologies. RIE can produce nano needles of silicon of varying heights and very low reflectance (less than $5 \%$ ) can be achieved. RIE is the most suitable process for obtaining low reflectance and is also cost effective. The change in the surface morphology, as function of process parameters, has been studied. The influence of pressure and etch time on the surface roughness and structure profile has been examined. The obtained roughness is compared with the study in the literature.

\section{Acknowledgements}

We thank Dr. Michael Ehlrich and Ms. Judith Sheft of NJIT/NJII, for providing partial funding for the project through NSF-I-Corps towards the processing of the wafers. This work has been performed in part at the Advanced Science Research Center (ASRC) Nano Fabrication Facility of the Graduate Center at the City University of New York (CUNY). We thank Dr. Vishal Narang and Dr. Jacob Trevino for helping us with materials processing.

\section{Conflict of interest}

\section{None.}

\section{References}

1. Kalem S, Werner P, Arthurson O, et al. Black silicon with high density and high aspect ratio nanowhiskers. Nanotechnology 2011;22(23):235307.

2. Otto M, Kroll M, Kaesebier T, et al. Conformal transparent conducting oxides on black silicon. Adv Mater. 2012;22(44):5035-5038.

3. Stubenrauch $M$, Fischer M, Kremin C, et al. Black siliconnew functionalities in microsystems. Micromech and Microeng. 2006;16(6):S82-S87.

4. Su Y, Li S, Zhao G. Optical properties of black silicon prepared by wet etching. J Mater Sci: Mater Electron. 2012;23(8):1558-1561.

5. Marthi SR, Sekhri S, Ravindra NM, et al. Optical properties of black 
silicon: An analysis. JOM. 2015;67(9):2154-2159.

6. Ravindra NM, Marthi SR, Sekhri S, et al. Modeling of optical properties of black silicon/crystalline silicon. J Sci Ind Metrol. 2015;1(1):1-7.

7. Marthi SR, Ravindra NM. Optical properties of passivation layers on black silicon. Contributed papers from MS\&T 2016. Salt Lake City, Utah; 2016.

8. Ravindra NM, Marthi SR, Sekhri S, et al. Black Silicon: Processing, Properties and Applications. Momentum Press, New York NY; 2016.

9. Wang Y, Liu YP, Liang HL, et al. Broadband antireflection on the silicon surface realized by Ag nanoparticle-patterned black silicon. Phys Chem Chem Phys. 2013;7(15):2345-2350.

10. Li X, Bohn P. Metal-assisted chemical etching in $\mathrm{HF} / \mathrm{H}_{2} \mathrm{O}_{2}$ produces porous silicon. Appl Phys Lett. 2000;77(16):2572-2574.

11. Lu YT, Barron AR. Nanopore-type black silicon anti-reflection layers fabricated by a one-step silver-assisted chemical etching. Phys Chem Chem Phys. 2013;15(24):9862-9870.

12. Huang ZP, Geyer N, Wernor P, et al. Metal-assisted chemical etching of silicon: A Review. Adv Mater. 2011;23(2):285-308.

13. Peng K, Hu J, Yan Y, et al. Fabrication of single crystalline silicon nanowires by scratching a silicon surface with catalytic metal particles. Adv Funct Mater. 2006;16(3):387-394.

14. Yoo JS, Parm IO, Gangopadhyay U, et al. Black silicon layer formation for application in solar cells. Sol Energy Mater Sol. Cells 2006;90(1819):3085-3093.

15. Branz HM, Yost VE, Ward S, et al. Nanostructured black silicon and the optical reflectance of graded-density surfaces. Appl Phys Lett. 2009;94(23):231121.

16. Jia $\mathrm{X}$, Zhou C, Wang W, et al. Optimization of the surface structure on black silicon for surface passivation. Nanoscale Research Letters. 2017;12(1):193.

17. Cullis A, Canham L. Visible light emission due to quantum size effects in highly porous crystalline silicon. Nature. 1991;353: 335-338.

18. Cullis AG, Canham LT, Calcott P, et al. The structural and luminescence properties of porous silicon. J Appl Phys. 1997;82(3): 909-965.

19. Liu X, Coxon PR, Peters M, et al. Black silicon: fabrication methods, properties and solar energy applications. Energy Environ Sci. 2014;7(10):3223-3263.

20. Vorobyev AY, Guo C. Direct femtosecond laser surface nano/ microstructuring and its applications. Laser Photonics Rev. 2013;7(3):385-407.
21. Her TH, Finlay RJ, Wu C, et al. Microstructuring of silicon with femtosecond laser pulses. Appl Phys Lett. 1998;73(12):1673-1675.

22. Her TH, Finlay RJ, Wu C, et al. Femtosecond laser-induced formation of spikes on silicon. Appl Phys A: Mater Sci Process. 2000;70(4):383-385.

23. Wu C, Crouch C, Zhao L, et al. Near-unity below-band-gap absorption by microstructured silicon. Appl Phys Lett. 2001;78(13):1850-1852.

24. Crouch CH, Carey JE, Warrender JM, et al. Comparison of structure and properties of femtosecond and nanosecond laser-structured silicon. Appl Phys Lett. 2004;84(11):1850-1853.

25. Sarnet T, Derrien T, Torres R, et al. Black silicon for photovoltaic cells: Towards a high-efficiency silicon solar cell. Proceedings of 28th European Photovoltaic Solar Energy Conference and Exhibition, Paris; 2013:1882-1886.

26. Sarnet T, Carey JE, Mazur E, et al. From black silicon to photovoltaic cells, using short pulse lasers. Proceedings of International Symposium on High Power Laser Ablation 2012, New Mexico; 2012:219.

27. Sundaram S, Mazur E. Inducing and probing non-thermal transitions in semiconductors using femtosecond laser pulses. Nat Mater. 2002;1:217224 .

28. Chowdhury ZR, Loh JYY, Pishon MD, et al. Black silicon morphologies using conventional RIE processing. AIP Advances. 2017;7(5):055115.

29. Jansen H, De Boer M, Legtenberg R, et al. The black silicon method: a universal method for determining the parameter setting of a fluorinebased reactive ion etcher in deep silicon trench etching with profile control. J Micromech Microeng. 1995;5(2):115-120.

30. Dussart R, Tillocher T, Lefaucheux P, et al. Plasma cryogenic etching of silicon: from the early days to today's advanced technologies. $J$ Phys $D$ : Appl Phys. 2014;47(12):123001.

31. Park KM, Lee MB, Jeon KS, et al. Reactive ion etching texturing for multicrystalline silicon solar cells using a $\mathrm{SF}_{6} / \mathrm{O}_{2} / \mathrm{Cl}_{2}$ gas mixture. Japanese Journal of Applied Physics. 2013;52(3S):03BD01.

32. Yoo J. Reactive ion etching (RIE) technique for application in crystalline silicon solar cells. Solar Energy. 2010;84(4):730-734.

33. Zhong S, Liu B, Xia Y, et al. Influence of the texturing structure on the properties of black silicon solar cell. Solar Energy Materials and Solar Cells. 2013;108:200-204.

34. Dekkers HFW, Duerinckx F, Szlufcik J, et al. Silicon surface texturing by reactive ion etching. Opto-Electronics Review. 2000;8(4):311-316. 